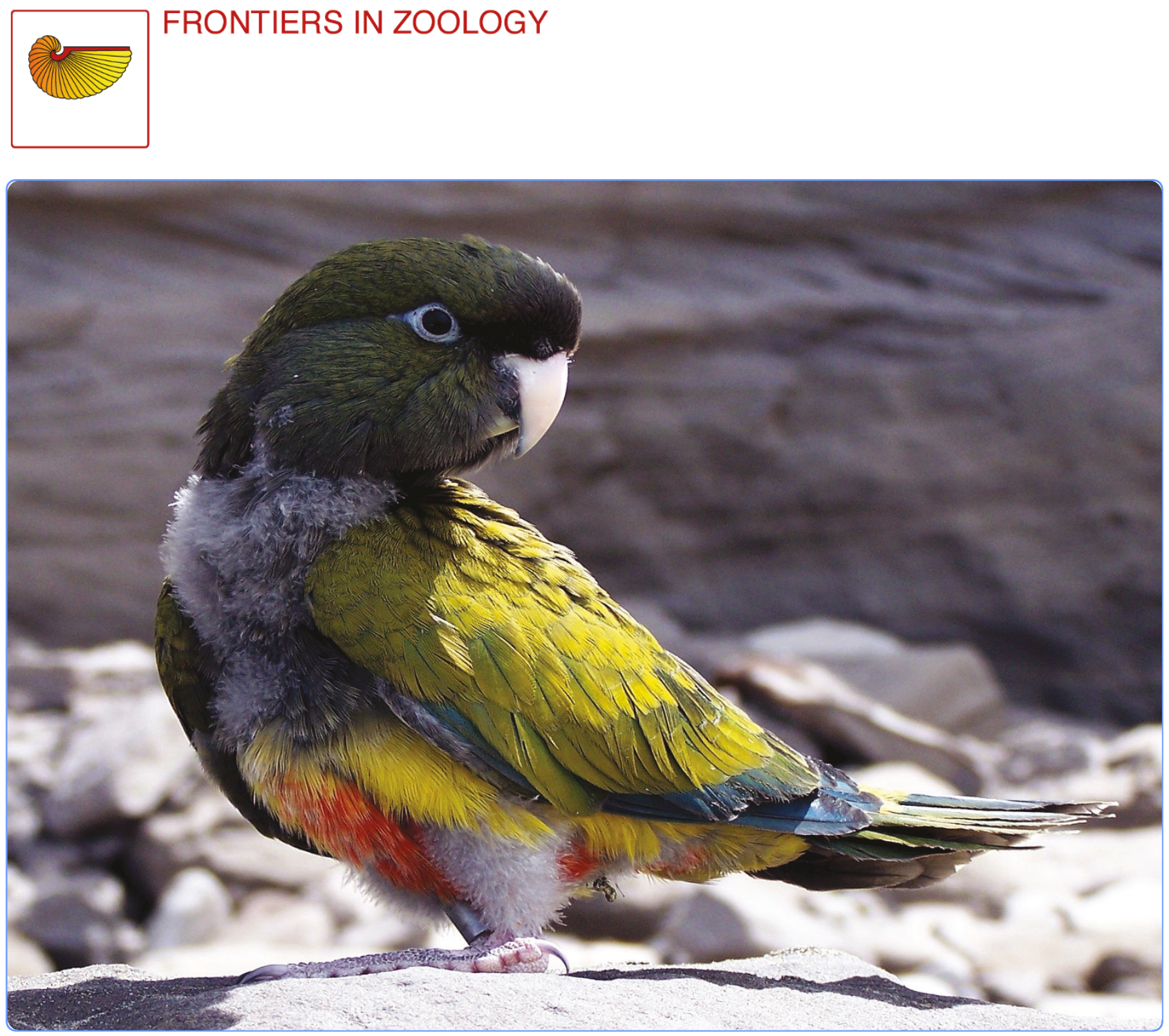

The high Andes, gene flow and a stable hybrid zone shape the genetic structure of a wideranging South American parrot

Masello et al. 


\title{
The high Andes, gene flow and a stable hybrid zone shape the genetic structure of a wide-ranging South American parrot
}

\author{
Juan F Masello ${ }^{1 *}$, Petra Quillfeldt ${ }^{1}$, Gopi K Munimanda², Nadine Klauke ${ }^{3}$, Gernot Segelbacher ${ }^{4}$, H Martin Schaefer $^{3}$, \\ Mauricio Failla ${ }^{5}$, Maritza Cortés ${ }^{6}$ and Yoshan Moodley ${ }^{2}$
}

\begin{abstract}
Background: While the gene flow in some organisms is strongly affected by physical barriers and geographical distance, other highly mobile species are able to overcome such constraints. In southern South America, the Andes (here up to 6,900 m) may constitute a formidable barrier to dispersal. In addition, this region was affected by cycles of intercalating arid/moist periods during the Upper/Late Pleistocene and Holocene. These factors may have been crucial in driving the phylogeographic structure of the vertebrate fauna of the region. Here we test these hypotheses in the burrowing parrot Cyanoliseus patagonus (Aves, Psittaciformes) across its wide distributional range in Chile and Argentina.
\end{abstract}

Results: Our data show a Chilean origin for this species, with a single migration event across the Andes during the Upper/Late Pleistocene, which gave rise to all extant Argentinean mitochondrial lineages. Analyses suggest a complex population structure for burrowing parrots in Argentina, which includes a hybrid zone that has remained stable for several thousand years. Within this zone, introgression by expanding haplotypes has resulted in the evolution of an intermediate phenotype. Multivariate regressions show that present day climatic variables have a strong influence on the distribution of genetic heterogeneity, accounting for almost half of the variation in the data.

Conclusions: Here we show how huge barriers like the Andes and the regional environmental conditions imposed constraints on the ability of a parrot species to colonise new habitats, affecting the way in which populations diverged and thus, genetic structure. When contact between divergent populations was re-established, a stable hybrid zone was formed, functioning as a channel for genetic exchange between populations.

\section{Background}

Current molecular genetic methods allow the understanding of the genetic structure underlying different populations of a species with previously unforeseen resolution [e.g. [1-3]]. As a result, it is possible to undertake fundamental investigations in ecology and evolution, like the study of the influence of past and current environmental conditions, together with ecological barriers, in shaping the population structure of wild animal species. These studies provide a unique opportunity to understand how species have evolved and how they are

\footnotetext{
* Correspondence: juan.masello@gmx.de

'Max Planck Institute for Ornithology, Vogelwarte Radolfzell, Radolfzell, Germany

Full list of author information is available at the end of the article
}

organised across landscapes [4]. The constraints that heterogeneous landscapes (e.g. barriers, resource distribution) and environmental conditions (e.g. climate) impose on the ability of animals to colonise new habitats have genetic implications affecting the structure, dynamics and persistence of populations [e.g. [5-9]]. Thus, significant genetic structuring can be expected among populations where gene flow is restricted [e.g. [5,10]].

However, when contact between divergent populations is re-established, hybrid zones can form with resultant consequences for the evolutionary trajectories of the interbreeding populations [e.g. [11]]. Two scenarios could potentially occur: if hybrid fitness is high, introgression will be widespread and hybridising populations

\section{Biomed Central}


may become panmictic over time, replacing the original populations [12]; but if interbreeding is limited in geographical range, hybridising populations may experience genetic exchange without panmixia [e.g. [13]]. Under such circumstances hybrid zones may persist over time and function as channels for genetic exchange between the populations, increasing overall levels of genetic and phenotypic diversity [e.g. [14-17]].

Although Pleistocene climate conditions played an important role in initiating major phylogeographical structuring in today's fauna [18], very little is known about their effects on southern South American terrestrial vertebrates. Phylogeographic studies in this region are scarce and have been conducted on rodents [19-21], lizards [22-24], amphibians [9,25], and a bird species [26]. Several of these studies suggested that the phylogeographic patterns observed, such as past fragmentation, range expansion, and secondary contact, could in part be understood in light of Pleistocene climate conditions. There is evidence of several cycles of more arid conditions intercalated with moist periods during the Pleistocene and Holocene of Southern South America [e.g. [27-30]], which were related to glaciation events [31], influencing the vegetation distribution [32] and the fauna depending on it.

One species that may allow hypotheses about gene flow both across a heterogeneous distribution, and into hybrid zones to be tested is the burrowing parrot (Cyanoliseus patagonus) (Aves, Psittaciformes). This species is distributed in a particularly heterogeneous arid to semi-arid landscape, across an extensive $\sim 1,000,000 \mathrm{~km}^{2}$ range in Chile and Argentina. A previous study [33] suggested that precipitation and temperature restrict burrowing parrot distribution in Argentina. According to this study [33], burrowing parrots are restricted to an area with median annual precipitation up to $600 \mathrm{~mm}$, and annual average temperatures of no less than $8^{\circ} \mathrm{C}$. However, this topic merits further research, as the study [33] was based on outdated distributional data and on the plain interpretation of maps, without detailed statistical analyses. The most dominant feature of this region is the high Andes, a mountain range that attains an altitude of up to $6,900 \mathrm{~m}$ and appears to separate burrowing parrot populations in Chile from those in Argentina. The predominant ecosystem on the Chilean side of this region is the 'Matorral', where vegetation is adapted to the generally dry conditions of a Mediterranean climate zone [34-36]. On the Argentinean side the semi-desert scrubland known as the 'Monte' is predominant, and this occurs from Patagonia to the North-west of Argentina [[37] and references therein]. Even though there are no extrinsic barriers to parrot dispersal in Argentina, more than $2,300 \mathrm{~km}$ separate the southernmost and northernmost burrowing parrot populations there. In addition, burrowing parrots breed in sandstone, limestone or earthen cliffs or "barrancas" (gorges or ravines), where they excavate nest burrows and form colonies [e. g. [37]]. These cliffs are heterogeneously located in the driest parts of the burrowing parrots range, being commonly found along permanent or temporary rivers, lakeshores, and the seacoast. Given the dryness of this environment, burrowing parrot colonies are never far from freshwater on which they are completely dependent, as they need to drink several times per day $[37,38]$ (Figure S1). These specific requirements for nest sites, which are spread over thousands of square kilometres, and water, together with the colossal barrier of the Andes, may favour the isolation of burrowing parrot breeding sites and a complex population structure driven by genetic drift.

Due to the heterogeneity of habitats within this species' range, four burrowing parrot sub-species have been proposed, three of which are found in Argentina: C. $p$. patagonus in Patagonia, C. $p$. andinus in the Cuyo region to the west and north-west, and C. p. conlara ranging in the San Luis region between the former two (hereafter patagonus, andinus, conlara) $[34,39,40]$. The sub-species C. p. bloxami (hereafter bloxami) is found on the Andean foothills of Central Chile [34,41]. Three of the sub-species, namely andinus, patagonus and blox$a m i$, are clearly morphologically distinct (size and plumage coloration) [34], while some authors [34,40,42] considered conlara a hybrid, owing to its intermediate geographic location and phenotype, between patagonus and andinus. Little is known about the genetic structure of burrowing parrots and how this corresponds to the morphological sub-species described above. A previous study [43] attempted to address this using seven microsatellite markers and suggested moderate differentiation between bloxami and all other subspecies, but differentiation within Argentinean samples was not detected. Analysis of a larger sample using a uniparental marker such a mitochondrial DNA may increase the resolution of genetic structure in this species.

Burrowing parrots are currently threatened by intense collection of birds for the pet trade [37], unjustified persecution as a crop pest $[41,44]$ and strong habitat loss and degradation, particularly in the Monte ecosystem [45]. The latter could strongly reduce connectivity among the populations, enhancing isolation. As key species in the Monte, any negative impact on burrowing parrots could potentially affect other species since their abandoned and semi-collapsed nests provide breeding space to many other cavity nesters (such as insects, reptiles, birds and small mammals) [46].

Given the marked phenotypic differences between the populations on both sides of the Andes we hypothesise that gene flow across this high mountain range, the 
largest barrier in the region, must be severely restricted. We tested this hypothesis using three mtDNA loci, in a large scale sampling effort covering almost the entire species range. We also aimed to uncover the underlying population structure of this species, determine their geographic origins and suggest possible routes of colonisation. We also used these data to determine if an andinus-patagonus hybrid zone exists. Lastly, considering the conservation value of this key species, its potentially restricted distribution with respect to climatic factors, and the unchecked degradation of their preferred habitats, we aim to ascertain the extent to which ecological and climatic factors influence their population structure.

\section{Methods Samples}

Recently, various aspects of the breeding biology of this species have been investigated extensively, providing the necessary framework for this study [e.g. [37,38,47-57]]. Fieldwork was carried out from November to December 2007 (Argentina), February 2008 (northern Chile) and from October to November 2008 (Argentina). Thirtythree colonies and eleven roosting places of the four previously proposed sub-species (bloxami, andinus, conlara and patagonus) were visited and naturally moulted feathers were non-invasively collected (Figure 1). Since burrowing parrots moult their primary feathers at the beginning of their breeding season, from November onwards $[38,58]$, collection is usually straightforward, as feathers tend to accumulate at the bottom of the cliffs with colonies. Taxonomic assignment of colonies was conducted following previous studies $[34,39]$. The southernmost populations of bloxami in Chile were not accessible.

\section{Molecular methods}

DNA was extracted from the feather quill, for a subset of 3 - 29 individuals from each of 44 populations using the DNAeasy blood and tissue kit (Qiagen, Germany). Mitochondrial genes cytochrome $b$ (cyt $b$ ), cytochrome oxidase subunit I (COI) and ATPase subunits 6/8 were amplified via PCR using the following mitochondrialspecific primers: L15424 5'- ATCCCATTCCACCAT ACTACTC, H15767 5'- ATGAAGGGATGTTCTACTACTGGTTG-3'( cyt $b, 586 \mathrm{bp})$ [59], COI-F 5'CCTGCAGGAGGAGGAGAYCC-3', COI-A 5'- AGTATAAGCGTCTGGGTAGTC-3' (COI, 455bp) [60], and CO2GQL 5'- GGACAATGCTCAGAAATCTGCGG-3', CO3HMH 5'- CATGGGCTGGGGTCRACTATGTG-3' (ATP6/8, 818bp) [61]. PCRs were conducted in $20 \mu \mathrm{l}$ reaction volumes containing $100 \mathrm{ng}$ DNA template, 10 $\mathrm{mM}$ of each primer, $10 \mathrm{mM}$ dNTPs (Roth, Karlsruhe), $3.125 \mathrm{mM} \mathrm{MgCl}, 5 \mathrm{U}$ Taq Polymerase (Qiagen Taq
Polymerase Core Kit) in a $1 \times$ PCR reaction buffer. PCR commenced with denaturation at $94^{\circ} \mathrm{C}$ for 3 minutes, followed by 35 cycles of denaturation at $95^{\circ} \mathrm{C}$ for $45 \mathrm{~s}$, annealing at $55^{\circ} \mathrm{C}(\mathrm{CO} 1, \mathrm{ATP} 6 / 8)$ or $52^{\circ} \mathrm{C}$ (cytb) for 45 $\mathrm{s}$ and extension at $72^{\circ} \mathrm{C}$ for $45 \mathrm{~s}$. A final extension step $\left(10 \mathrm{~min}\right.$ at $\left.72^{\circ} \mathrm{C}\right)$ concluded the PCR. Products were checked on a $1 \%$ agarose gel and purified of primers and excess dNTPs using either exonuclease-shrimp alkaline phosphatase (Fermentas Life Sciences) or the MinElu-te PCR Purification Kit (Qiagen), following the manufacturers specifications. PCR products were then sequenced in both directions by either Qiagen (Qiagen GmbH, Sample \& Assay Technologies, Hilden, Germany) or by using Big Dye chemistry (Applied Biosystems) and run on an $A B 3130 x l$ genetic analyser (Applied Biosystems). Sequences were checked, edited and aligned in CLC DNA Workbench 5.5 (CLC bio). A total of 150 individuals from 41 of the attempted 44 locations were suitable for downstream analyses (Table 1, 2, 3 and 4; see also Additional file 1 Table S1).

\section{Analyses}

Genetic variation was quantified as the number of haplotypes, nucleotide and haplotype diversity per population, and was determined using DnaSP v5 [62]. The degree of population structuring was ascertained using a Bayesian population assignment model that assumes noadmixture and that loci are linked BAPS 5 [63]. Unlike other clustering algorithms, this BAPS module allows the assumption of linkage between loci, thereby enabling population assignments using multilocus mtDNA data. The simulation was run ten times for $K_{\max }$ values of five, ten and 20 potential populations.

Phylogenetic structuring among haplotypes was investigated by maximum likelihood (ML) in Treefinder $[64,65]$, which first determined the best-fit substitution model for each gene partition. ML analyses was carried out assuming the $\mathrm{HKY}+\mathrm{G}(\mathrm{cyt} b), \mathrm{HKY}+\mathrm{I}(\mathrm{CO} 1)$ and J2 $+\mathrm{G}(\mathrm{CO} 2 / 3)$ models, each optimising rate, frequency and heterogeneity parameters directly from the data. Models including a rate-heterogeneity parameter $(+G)$ assumed five gamma categories. The significance of nodal bi-partitions was determined by 1,000 bootstrap replicates, from which an $80 \%$ majority rule consensus tree was constructed. We also constructed a medianjoining network using Network 4.5.1.6 [66] for a graphical representation of the unrooted relationships and frequency of haplotypes.

Demographic parameters based on the coalescent can be useful in testing hypotheses of population history. In particular, statistics based on the distribution of pairwise differences (mismatch distribution) [67] between individuals in a population as well as the detection of selection among selectively neutral loci may be used as 


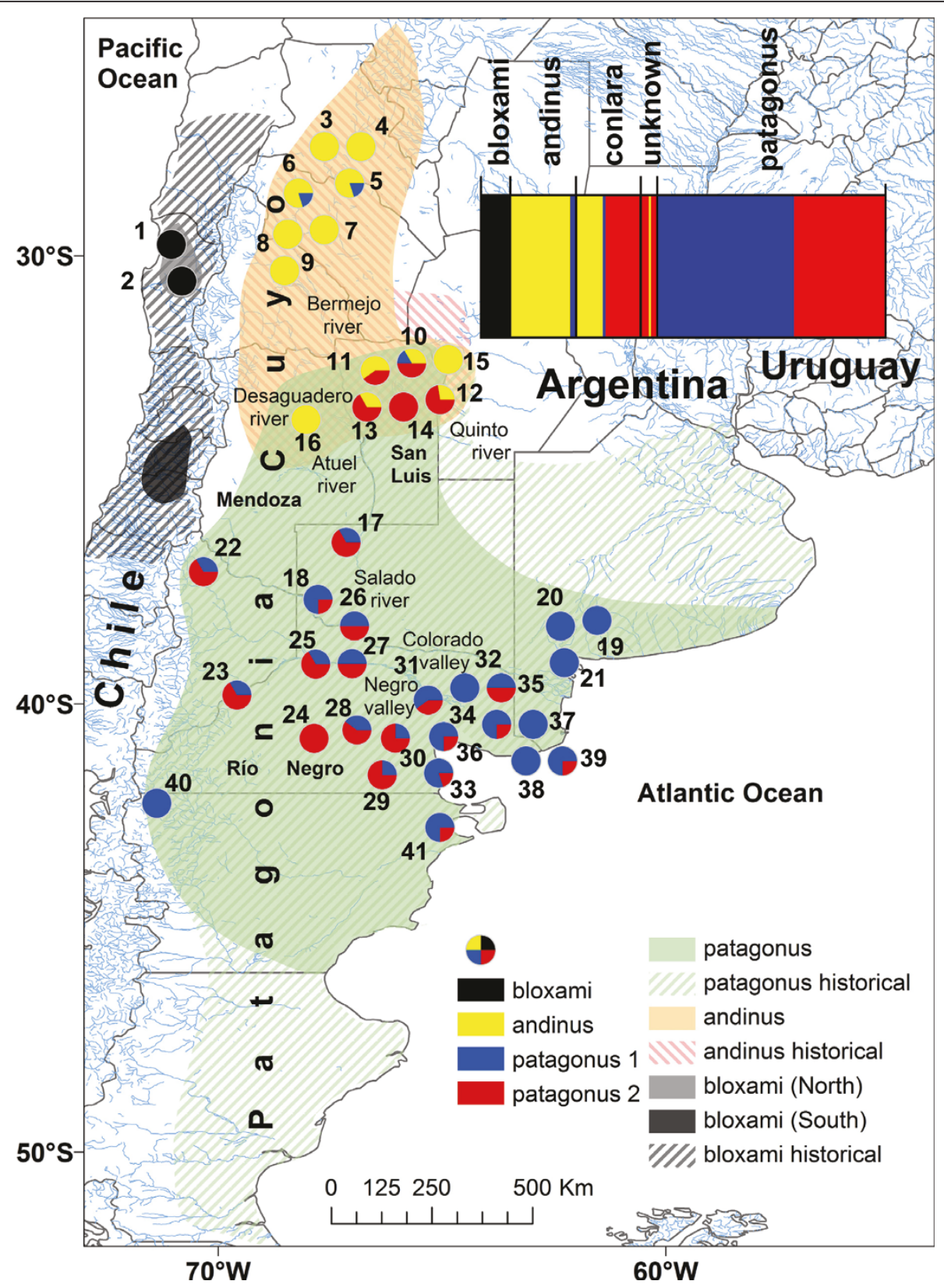

Figure 1 The distribution of burrowing parrot (Cyanoliseus patagonus) haplotypes in Chile and Argentina. The historical (dashed areas) and current distribution (coloured areas) of the different morphological subspecies is depicted. The proportion of haplotypes at each sampling location (see Additional file 1 Table S1 and Additional file 2 Table S2) that were assigned to different burrowing parrot populations is displayed in population pie charts. Numbers correspond with each sampling location (see Table 1). The inset shows the plot of the Bayesian assignments for all sampled individuals to an optimal four populations as determined by BAPS v5 (mixture model). The individuals are grouped taxonomically.

signatures of past population expansion events. We used Arlequin 3.5 [68] to calculate the mismatch distributions and Fu's Fs for all populations identified by the clustering and phylogenetic methods above.

We roughly dated each node using a fossil calibration technique that incorporates rate smoothing for lineages with unequal rates of evolution. By constraining the tree topology to that of the $80 \%$ majority rule consensus tree calculated previously, we generated a range of node height estimates by running a bootstrap analyses 1,000 times in Treefinder, using the original starting parameters. The variance in node height was then taken as the spread of this variable in our data set. The fossil record for $C$. patagonus is extremely scarce, with three known fossils dated to $126 \mathrm{kyr}$ [69-72]. A much earlier fossil that can also be attributed to the genus 
Table 1 Summary of DNA polymorphism of burrowing parrots (Cyanoliseus patagonus) from Northern Chile and Catamarca, La Rioja, and San Juan in Argentina

\begin{tabular}{|c|c|c|c|c|c|c|c|c|c|c|}
\hline Locality & ER & Source & Spp. & PS & $S$ & A & $\mathbf{N}$ & $\mathbf{H}$ & $\mathrm{Hd}$ & $\mathrm{Pi}(J C)$ \\
\hline \multicolumn{11}{|l|}{ CHILE } \\
\hline \multicolumn{11}{|l|}{ IV Región } \\
\hline 1) Santa Gracia & MAT & C & bloxami & 75 & 29 & 29 & 4 & 4 & 1.000 & 0.00260 \\
\hline 2) Quebrada de San Carlos & MAT & C & bloxami & 400 & 29 & 29 & 7 & 4 & 0.714 & 0.00123 \\
\hline \multicolumn{11}{|l|}{ ARGENTINA } \\
\hline \multicolumn{11}{|l|}{ Catamarca } \\
\hline 3) Los Morteros, Abaucán river & MSB & C & andinus & 100 & 15 & 11 & 4 & 2 & 0.500 & 0.00054 \\
\hline 4) Salado river & MSB & C & andinus & 90 & 10 & 5 & 2 & 2 & 1.000 & 0.00162 \\
\hline \multicolumn{11}{|l|}{ La Rioja } \\
\hline 5) San Blas & MSB & C & andinus & 20 & 20 & 7 & 5 & 3 & 0.800 & 0.00237 \\
\hline 6) affluent, Vinchina river & MSB & C & andinus & 60 & 20 & 14 & 5 & 3 & 0.700 & 0.00216 \\
\hline 7) Los Tambillos & MSB & C & andinus & 10 & 4 & 4 & 2 & 2 & 1.000 & 0.00162 \\
\hline 8) Zanja de la viuda & MSB & C & andinus & 15 & 7 & 7 & 1 & 1 & 0 & 0 \\
\hline \multicolumn{11}{|l|}{ San Juan } \\
\hline 9) Huaco & MSB & C & andinus & 20 & 4 & 4 & 2 & 2 & 1.000 & 0.00162 \\
\hline
\end{tabular}

Eco-regions: MAT, matorral; MSB, monte de sierras y bolsones; CHS, Chaco seco; ESP, espinal; MLM, monte de llanuras y mesetas; PAM, pampa; ETP, estepa patagónica. ER: eco-region; Source, origin of the feathers used to obtain DNA: C, colony; RP, roosting place; Spp., morphological sub-species according to [34,39]; PS, estimated size of studied populations: nests in the case of colonies, individuals in roosting places; $\mathrm{S}$, number of feathers collected; A, number of samples for which sequencing was attempted; $\mathrm{N}$, the number of sequences; $\mathrm{H}$, number of haplotypes; $\mathrm{Hd}$, haplotype diversity; Pi, nucleotide diversity

Table 2 Summary of DNA polymorphism of burrowing parrots (Cyanoliseus patagonus) from San Luis, Córdoba, Mendoza, La Pampa, Buenos Aires and Neuquén in Argentina

\begin{tabular}{|c|c|c|c|c|c|c|c|c|c|c|}
\hline Locality & ER & Source & Spp. & PS & $\mathrm{S}$ & A & $\mathbf{N}$ & $\mathrm{H}$ & $\mathrm{Hd}$ & $\mathrm{Pi}(\mathrm{JC})$ \\
\hline \multicolumn{11}{|l|}{ San Luis } \\
\hline 10) San Martín stream & $\mathrm{CHS}$ & C & conlara & 180 & 8 & 8 & 6 & 4 & 0.800 & 0.00360 \\
\hline 11) Las Chacras & $\mathrm{CHS}$ & C & conlara & 170 & 12 & 7 & 5 & 4 & 0.900 & 0.00421 \\
\hline 12) Paso Grande & ESP & $\mathrm{RP}$ & conlara & $1500^{a}$ & 32 & 15 & 11 & 6 & 0.727 & 0.00300 \\
\hline 13) San Luis & $\mathrm{CHS}$ & C & Undetermined & 20 & 8 & 5 & 3 & 3 & 1.000 & 0.00360 \\
\hline 14) Quinto river & ESP & C & Undetermined & 100 & 15 & 5 & 3 & 3 & 1.000 & 0.00144 \\
\hline \multicolumn{11}{|l|}{ Córdoba } \\
\hline 15) Piedras Blancas stream & $\mathrm{CHS}$ & C & conlara & 100 & 11 & 7 & 2 & 1 & 0.000 & 0.00000 \\
\hline \multicolumn{11}{|l|}{ Mendoza } \\
\hline 16) Pichi Ciego & MLM & C & andinus & 50 & 11 & 7 & 3 & 3 & 1.000 & 0.00216 \\
\hline \multicolumn{11}{|l|}{ La Pampa } \\
\hline 17) Algarrobo del Aguila & MLM & $\mathrm{RP}$ & patagonus & 2000 & 15 & 8 & 6 & 5 & 0.933 & 0.00230 \\
\hline 18) Colorado river & MLM & C & patagonus & 660 & 52 & 9 & 4 & 2 & 0.500 & 0.00162 \\
\hline \multicolumn{11}{|l|}{ Buenos Aires } \\
\hline 19) Sierra de la Ventana & PAM & C & patagonus & 50 & 21 & 6 & 4 & 2 & 0.500 & 0.00027 \\
\hline 20) Tornquist & PAM & C & patagonus & 40 & 1 & 1 & 1 & 1 & 0 & 0 \\
\hline 21) Bahía Blanca & ESP & $\mathrm{RP}$ & patagonus & 3000 & 29 & 7 & 3 & 1 & 0 & 0 \\
\hline \multicolumn{11}{|l|}{ Neuquén } \\
\hline 22) Tricao Malal & ETP & C & patagonus & Unknown & 4 & 4 & 3 & 2 & 0.667 & 0.00180 \\
\hline 23) Bajada Colorada & MLM & C & patagonus & 1060 & 77 & 8 & 3 & 3 & 1.000 & 0.00180 \\
\hline
\end{tabular}

For abbreviations see Table 1

a Source [83] 
Table 3 Summary of DNA polymorphism of burrowing parrots (Cyanoliseus patagonus) from Río Negro and Chubut in Argentina

\begin{tabular}{|c|c|c|c|c|c|c|c|c|c|c|}
\hline Locality & ER & Source & Spp. & PS & $\mathrm{S}$ & $A$ & $\mathrm{~N}$ & $\mathrm{H}$ & $\mathrm{Hd}$ & $\mathrm{Pi}(J \mathrm{C})$ \\
\hline \multicolumn{11}{|l|}{ Río Negro } \\
\hline 24) Los Menucos & ETP & $\mathrm{RP}$ & patagonus & 300 & 54 & 8 & 2 & 2 & 1.000 & 0.00269 \\
\hline 25) Paso Córdoba & MLM & C & patagonus & 10 & 10 & 6 & 3 & 3 & 1.000 & 0.00287 \\
\hline 26) Casa de Piedra & MLM & C & patagonus & 40 & 22 & 8 & 4 & 3 & 0.833 & 0.00162 \\
\hline 27) Villa Regina & MLM & C & patagonus & 50 & 13 & 8 & 2 & 2 & 1.000 & 0.00323 \\
\hline 28) Ministro Ramos Mexía & MLM & $\mathrm{RP}$ & patagonus & 300 & 33 & 9 & 5 & 3 & 0.700 & 0.00183 \\
\hline 29) El Tembrao & MLM & $\mathrm{RP}$ & patagonus & 300 & 91 & 9 & 4 & 4 & 1.000 & 0.00242 \\
\hline 30) Valcheta & MLM & $\mathrm{RP}$ & patagonus & 300 & 34 & 8 & 4 & 4 & 1.000 & 0.00171 \\
\hline 31) El Solito & MLM & C & patagonus & 130 & 20 & 8 & 5 & 5 & 1.000 & 0.00248 \\
\hline 32) El Saladar, Bajo del Gualicho & MLM & $C$ & patagonus & 5 & 1 & 1 & 1 & 1 & 0 & 0 \\
\hline 33) Las Grutas & MLM & C & patagonus & 420 & 17 & 6 & 5 & 3 & 0.700 & 0.00162 \\
\hline 34) San Antonio Oeste & MLM & $\mathrm{RP}$ & patagonus & 20 & 30 & 6 & 4 & 3 & 0.833 & 0.00180 \\
\hline 35) Conesa & MLM & $\mathrm{RP}$ & patagonus & 2,000 & 32 & 13 & 2 & 2 & 1.000 & 0.00323 \\
\hline 36) raft area, Guardia Mitre & MLM & C & patagonus & 140 & 25 & 4 & 4 & 2 & 0.500 & 0.00135 \\
\hline 37) IDEVI & MLM & $\mathrm{RP}$ & patagonus & 2,000 & 11 & 4 & 3 & 2 & 0.667 & 0.00036 \\
\hline 38) La Lobería & MLM & C & patagonus & 3,700 & 30 & 6 & 3 & 2 & 0.667 & 0.00108 \\
\hline 39) El Cóndor & MLM & C & patagonus & 37,000 & 49 & 4 & 4 & 3 & 0.833 & 0.00162 \\
\hline \multicolumn{11}{|l|}{ Chubut } \\
\hline 40) La Mina river & ETP & C & patagonus & 5 & 5 & 5 & 2 & 2 & 1.000 & 0.00054 \\
\hline 41) Puerto Madryn & MLM & C & patagonus & 20 & 10 & 7 & 4 & 3 & 0.833 & 0.00171 \\
\hline
\end{tabular}

For abbreviations see Table 1

Cyanoliseus dates back to 750 kya [70-73]. However, since the nearest outgroup taxon for which molecular data were available belonged to the genus Diopsittaca, it was not possible to utilise the older fossil date in our calibration. We therefore assumed a minimum or latest date of $126 \mathrm{kyr}$ for the coalescence of all C. patagonus lineages. We then performed the calibration analysis in Treefinder and, due to the availability of a single calibration date, we used local rate minimum deformation rate-smoothing, to account for the possibility of differing rates of lineage evolution within the phylogeny. 95\% confidence intervals were generated from the spread of node heights.

We investigated the possibility of differing mutation rates among the three gene partitions in order to independently date each node using available mutation rates.
However, since reliable mutation rates are currently only available for the avian cytochrome $b$ gene [74], we partitioned the sequence data into cyt $b$ and $\mathrm{CO} 1+\mathrm{CO} 2 /$ 3 and performed identical analyses in BEAST 1.5.0 [75], using the parameter-rich GTR+G+I model (with 5 gamma categories) to check if cyt $b$ mutation rates may be applied to other mitochondrial data. Plotting the resulting cyt $b$ node heights against those of $\mathrm{CO} 1+\mathrm{CO} 2 /$ 3 returned a correlation co-efficient $\left(\mathrm{R}^{2}\right)$ value of 0.5858 ( $\mathrm{p}<0.001$, data not shown), suggesting significantly differing rates of evolution between the two gene partitions. As a rate-smoothing option is unavailable in BEAST, we proceeded with only the cytochrome $b$ data, using both the average avian mutation rate $(\mu)$ of $2.1 \%$ / million years (myr) and a Psittaciform-specific rate of $3.4 \% /$ myr [74].

Table 4 Summary of DNA polymorphism of burrowing parrots (Cyanoliseus patagonus)

\begin{tabular}{|c|c|c|c|c|c|c|c|}
\hline \multirow[b]{2}{*}{ Sub-species } & \multirow[b]{2}{*}{ Estimated total population size } & \multicolumn{2}{|c|}{ PS } & \multirow[t]{2}{*}{$\mathbf{N}$} & \multirow[t]{2}{*}{$\mathbf{H}$} & \multirow[t]{2}{*}{ Hd } & \multirow[t]{2}{*}{$\mathrm{Pi}(J C)$} \\
\hline & & C & $\mathrm{RP}$ & & & & \\
\hline andinus & 2,000 nests $^{a}$ & 365 & & 24 & 13 & 0.888 & 0.00206 \\
\hline bloxami & $5,000-6,000$ individuals ${ }^{b}$ & 475 & & 11 & 6 & 0.800 & 0.00163 \\
\hline $\begin{array}{l}\text { conlara } \\
\text { (and "undetermined") }\end{array}$ & 1,700 individuals $^{c}$ & 570 & $1,500^{c}$ & 30 & 12 & 0.798 & 0.00320 \\
\hline patagonus & 43,330 nests $^{d}$ & 43,330 & 10,220 & 85 & 25 & 0.890 & 0.00205 \\
\hline Total sample & & & & 150 & 51 & 0.943 & 0.00530 \\
\hline
\end{tabular}

For abbreviations see Table 1.

Sources: ${ }^{\mathrm{a}}[90]$ and this study, ${ }^{\mathrm{b}}[41,85]{ }^{\mathrm{C}}[83]{ }^{\mathrm{d}}[37]$ and this study 
Given the possibility of a relatively recent divergence and the apparent reliance of burrowing parrots on their habitat and associated climate [33,37], we also investigated the extent to which taxonomic, ecological and climatic factors influenced the distribution of genetic heterogeneity in the data. We fitted a linear model to our data using DISTLM 5 [76], thereby testing the influence of 32 variables (4 taxonomic, 7 ecological and 21 climatic; Table 5 and Table S1) using multiple matrix regressions. The climatic variables were selected taking into account the possible restriction of burrowing parrots distribution to certain temperature and precipitation ranges as suggested in a previous study [33]. The 21 temperature- and precipitation-related climatic variables were obtained, for each of the burrowing parrot colonies, with DIVA-GIS 7.1.7.2. [http://www.diva-gis. org], which are based on the WorldClim database [http://www.worldclim.org], version 1.3, at 2.5 minutes resolution [77]. We first assessed the marginal genetic variation explained by each set of variables separately. Since some of these variables are likely to co-vary with geography (latitude and longitude of sample locations), we controlled for this influence by also reporting the conditional residual variation remaining after the influence of geography was subtracted. Still controlling for geography, we then tested all variables together using a forward selection approach [78], which sequentially determines the variables that explained the majority of the marginal variation in the data. The significance of all DISTLM regressions was determined by 9,999 permutations.

To explore the influence of the geographic landscape in more detail, we used a spatial clustering algorithm, implemented in Tess 2.3.1 [79]. This method performs Bayesian clustering given a set of input sampling locations. The program constructed Dirichlet cells around each sampling location to produce a Voronoi tessalation. Multilocus DNA sequences were then used to statistically

Table 5 Results of the multivariate multiple regressions

\begin{tabular}{|c|c|c|c|}
\hline \multirow[t]{2}{*}{ Predictor Variable } & \multicolumn{3}{|c|}{ Proportion of the explained genetic variation } \\
\hline & Marginal & Conditional & Sequential \\
\hline Phenotype (sub-species definition) & 0.2204 & 0.0156 & 0.0010 \\
\hline Ecoregions & 0.0081 & 0.0075 & 0.0010 \\
\hline Climate (all variables) & 0.8529 & 0.4812 & 0.4812 \\
\hline \multicolumn{4}{|l|}{ Climate (per variable) } \\
\hline Temperature Seasonality (SD * 100) & 0.4856 & 0.2797 & 0.2797 \\
\hline Precipitation Seasonality (CV) & 0.4118 & 0.1427 & 0.1100 \\
\hline Mean Monthly Temperature Range & 0.1216 & 0.0472 & 0.0207 \\
\hline Precipitation of Wettest Quarter (mm) & 0.0379 & 0.0249 & 0.0197 \\
\hline Minimum Temperature of Coldest Month & 0.0195 & 0.0012 & 0.0154 \\
\hline Temperature Annual Range & 0.3210 & 0.1919 & 0.0130 \\
\hline Isothermality $(2 / 7)(* 100)$ & 0.4364 & 0.2165 & 0.0106 \\
\hline Precipitation of Driest Quarter (mm) & 0.2885 & 0.0685 & 0.0079 \\
\hline Mean Temperature of Wettest Quarter & 0.1566 & 0.0846 & 0.0028 \\
\hline Precipitation of Coldest Quarter (mm) & 0.0463 & 0.0080 & 0.0012 \\
\hline Precipitation of Warmest Quarter (mm) & 0.0786 & 0.0552 & - \\
\hline Mean monthly minimum Temperature & 0.0734 & 0.0605 & - \\
\hline Mean Temperature of Coldest Quarter & 0.0510 & 0.0089 & - \\
\hline Mean Temperature of Warmest Quarter & 0.2424 & 0.1662 & - \\
\hline Mean Temperature of Driest Quarter & 0.0634 & 0.0461 & - \\
\hline Annual Mean Temperature & 0.1296 & 0.0894 & - \\
\hline Precipitation of Wettest Month (mm) & 0.0312 & 0.0207 & - \\
\hline Annual Precipitation & 0.0830 & 0.0480 & - \\
\hline Mean monthly maximum Temperature & 0.1615 & 0.0988 & - \\
\hline Precipitation of Driest Month (mm) & 0.2880 & 0.0743 & - \\
\hline Maximum Temperature of Warmest Month & 0.2987 & 0.1965 & - \\
\hline
\end{tabular}

Analyses were carried out for 150 individual mitochondrial sequences of burrowing parrots, 21 bio-climatic parameters, morphological subspecies identity, and Chilean and Argentinean eco-regions.

- , added $<0.000001$ to the regression sum of squares; CV: coefficient of variation; SD: standard deviation. No. of permutations $=9999$. Temperature Seasonality: the standard deviation of the weekly mean temperatures expressed as a percentage of the mean of those temperatures (i.e. the annual mean). Precipitation Seasonality: the standard deviation of the weekly precipitation estimates expressed as a percentage of the mean of those estimates (i.e. the annual mean). See also Additional file 1 Table S1. 
infer population structure based on this Voronoi neighbourhood system using a hidden Markov random field prior. Parameter space was explored by Markov chain simulations. We ran the program ten times again with a $\mathrm{K}_{\max }$ of five, ten and 20, assuming no-admixture at 50,000 sweeps each, with a burn-in of 10,000 sweeps. We also included 23 dummy points, well outside the extant distribution C. patagonus, in order to restrict the simulation to within the species range. The resulting hard-clustering image represents the geographical clustering of individuals in landscape space, given their sampling origins and their multilocus genotypes. To allow the optimal tessalation to be viewed in geographic space, the hard clustering image with the lowest deviance information criterion (DIC) score was imported into ArcGIS 9.3, and superimposed onto a map of the region.

\section{Results \\ Genetic variation}

Complete sequences for all three mitochondrial fragments were obtained for 150 individuals from 41 locations (Tables 1, 2, $3 \& 4$, and Additional file 1 Table S1), representing 7 ecoregions and encompassing the entire species range. However, since the quality of DNA isolated from shed feathers was low, this number was less than half of the 327 individuals from which DNA was extracted. Genetic variation was also low, with only 81 polymorphic sites from a concatenated sequence of $1,859 \mathrm{bp}$, resulting in 51 unique haplotypes (Tables 1, 2, 3 \&4, and Additional file 2 Table S2). This was reflected in a species-wide haplotype diversity of 0.943 and nucleotide diversity of 0.00530 (Table 4), and given varying locality samples sizes these values ranged from $0.500-1.000$ and from $0-0.0360$ respectively (Tables 1 , 2, \&3). Considering taxonomic designations, conlara was found to have the highest nucleotide diversity. Nonconlara sampling localities, contained similar levels of diversity, with the exception of eight localities with a nucleotide diversity of less than 0.001 . This is reduced to only four localities, if we exclude those with fewer than 3 individuals.

\section{Genetic structure}

Despite low diversity, Bayesian clustering consistently structured the entire sample into four population clusters regardless of the $\mathrm{K}_{\max }$ prior, and the distributions of these are depicted in Figure 1. One of the four populations corresponded exactly to the bloxami phenotype, and was found exclusively on the Chilean side of the species range (inset, Figure 1). Within Argentina, only two members of the northern andinus phenotype did not fall within an Andinus population cluster, and the patagonus phenotype was divided into two populations, hereafter called Patagonus1 and Patagonus2. There was no support for the existence of the intermediate conlara, as this phenotype clustered either within the Andinus or Patagonus2 populations, with a single conlara clustered within Patagonus1.

Maximum likelihood analysis recovered a fully resolved haplotype phylogeny (Figure 2A) again showing four population groups, but with Bloxami as basal and distinct from all other populations. Within Argentina, the northern Andinus forms a sister relationship with the entire Patagonus population, with the two most ancestral haplotypes of the latter sampled in the Cuyo region (locations 3 to 9, and 16, Figure 1), among phenotypically andinus populations. In Patagonia, the patagonus subspecies is divided into the genetically distinct populations Patagonus1 and Patagonus2, yet without distinguishing phenotypic characteristics. A median-joining haplotype network (Figure 2B) confirmed the large divergence separating populations on either side of the Andes, but also demonstrated that all three Argentinean populations contain star-shaped haplotype clusters in which several less-frequent haplotypes are very closely related to a single common haplotype. Both phylogeny and network showed that individuals identified as conlara or "undetermined" (where phenotype could not be assigned to andinus or patagonus with certainty) belonged to either the Andinus (11/33 individuals; 5/14 haplotypes) or Patagonus (Patagonus1: 1/55 individuals, 1/15 haplotypes; Patagonus2: 18/51 individuals, 6/16 haplotypes) populations (Figure $2 \mathrm{~A} / \mathrm{B}$ ), confirming a hybrid origin for this phenotype. The six undetermined individuals (5 haplotypes) that were sampled within the conlara range from a population near the town of San Luis and from the Quinto river were most closely related to confirmed conlara haplotypes on the medianjoining network (Figure 2B), showing that both populations are admixed and therefore belong within conlara.

\section{Population History}

Mismatch distributions of pair-wise nucleotide differences (Figure 2C) showed largely unimodal distributions among Argentinean populations, but was multimodal within the Chilean Bloxami. Bloxami was also the only population where the hypothesis of a sudden population expansion was rejected $(\mathrm{p}(\mathrm{SSD})=0.0290)$. Furthermore, negative and significant Fu's Fs values, also indicating population expansion, were recovered for Andinus, Patagonus1 and Patagonus2, with the slightly negative value for Bloxami not significant. Assuming a fossil calibration of at least $126 \mathrm{kyr}$ for the coalescence of all C. patagonus lineages, we estimated dates for all population nodes to between 9 and 55 kya (Additional file 3 Table S3). Applying the average avian mutation rate $(\mu=$ $2.1 \% / \mathrm{myr}$ ) to the cytochrome $b$ data returned higher nodal divergence estimates with much larger 95\% 


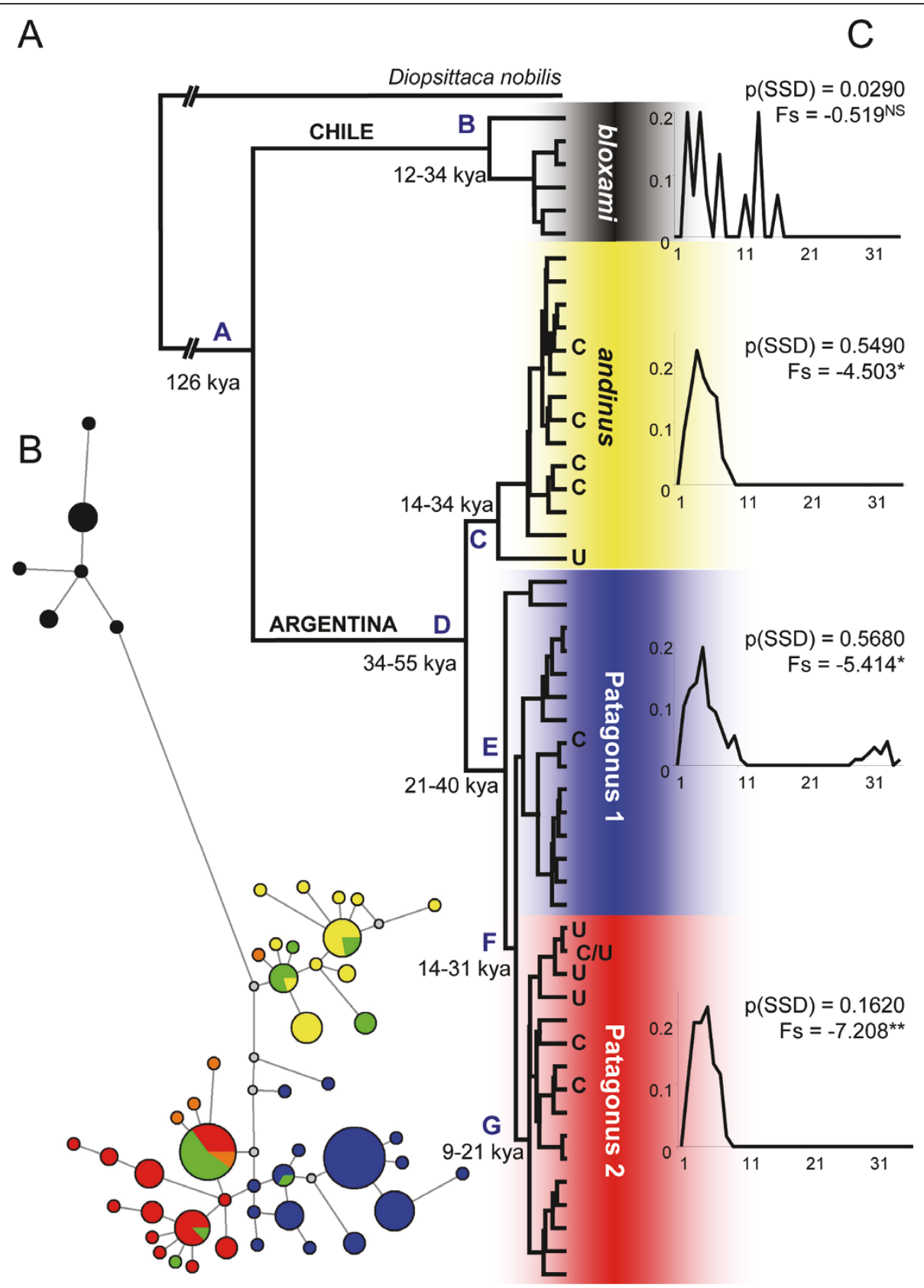

Figure 2 Phylogenetic relationships and population history among burrowing parrot (Cyanoliseus patagonus) populations. A. $80 \%$ majority-rule maximum likelihood phylogeny of 51 mitochondrial haplotypes. Nodal dates were determined assuming the coalescence of all lineages by at least 126 kya. The phylogeny was rooted by a Diopsittaca nobilis individual. B. A median-joining network showing the unrooted relatedness between haplotypes. Distances are proportional to the number of mutational changes and the size of each circle is proportional to haplotype frequency. The smallest grey circles denote unsampled haplotypes invoked by the median-joining algorithm. C. Mismatch distributions, the probability of rejecting the null hypothesis of a sudden population expansion p(SSD) and Fu's Fs statistic for all four populations. All clades and haplotypes are colour-coded according to Figure 1. Haplotypes belonging to the morphological sub-species conlara according to $[34,39]$ are marked with " $\mathrm{C}$ " in panel $\mathrm{A}$ and are coloured green in panel $\mathrm{B}$. Haplotypes where the phenotype could be assigned to neither andinus nor patagonus with certainty are denoted with " $U$ " in panel A and are orange in panel B. Node references are in blue alphabet. 
confidence intervals. However, the psittaciform-specific mutation rate $(\mu=3.4 \% / \mathrm{myr})$ yielded estimates very similar to those of the fossil calibration method. Owing to the larger variance of BEAST estimates, the 95\% interval of almost all fossil calibration dates was contained entirely within the psittaciform-rate interval (Additional file 3 Table S3). The only exception being node $\mathrm{E}$, although both fossil and $\mu$ estimates did overlap. Indeed, if a divergence time ( $T$ ) of $126 \mathrm{kyr}$ for all burrowing parrots was substituted into the equation $\mu=$ node height $/ 2 T$, a mutation rate of $3.5 \% /$ myr would result, implying that the cytochrome $b$ gene evolves more rapidly among psittaciform species. The $95 \%$ confidence intervals of the fossil calibrated population nodes reflect the stochasticity in the maximum likelihood estimation and the lack of internal calibration nodes. Their accuracy, therefore, relies heavily on that of the $126 \mathrm{kyr}$ fossil estimate, for which there exist three independently dated fossils [69-72]. In contrast, the much larger variance of BEAST estimates may reflect the limitations of using only a third of the total available data. We therefore continue with the more accurate fossil calibrated estimates (Figure 2A), and we view these as the latest range of dates by which each lineage splitting event could have occurred.

\section{Influences on genetic variation}

Since extant burrowing parrot populations appear to have evolved relatively recently, one might expect to find genetic structure to be associated to present-day ecological and environmental variables. The amount of marginal variation explained by predictor variables was highest for the suite of 21 climatic variables (85\%) followed by phenotype (22\%) and lastly ecoregions $(0.81 \%)$. This pattern held true even when the variation attributable to geography was removed in conditional tests (Table 5). When each climatic variable was tested individually, temperature seasonality, isothermality, temperature annual range, mean temperature of warmest quarter and maximum temperature of warmest month could all account for more than $15 \%$ of the conditional variation in the data set. When autocorrelations between these variables were taken into account in sequential tests, only temperature seasonality $(28 \%)$ and precipitation seasonality $(11 \%)$ were found to explain more than $10 \%$ of the genetic variation (Table 5 ).

The $44 \%$ of genetic variation explained by geography was partitioned into the four already-defined population clusters by TESS software. The optimal tessellation cluster was obtained consistently for all runs and for all starting $K_{\max }$ values and this partitioned Chilean from Argentinean populations, as have previous analyses (Figure 2). Spatial structuring within Argentina describes genetically Andinus haplotypes in the Cuyo region, to the north of the species range, whereas in Patagonia, Patagonus1 inhabits the entire Atlantic coast and a thin wedge between southern limit of Andinus and the north of the Río Colorado valley (Figure 3). The Patagonus2 population occupies a non-contiguous area along the entire course of the Río Colorado and except for a population in which Patagonus1 is particularly dominant, also the entire course of the Río Negro until just before it enters the Atlantic Ocean. Some Patagonus2 haplotypes also range north into the San Luis region, which is the southern-eastern end of the Andinus distribution, where hybridization with Andinus results in the conlara phenotype.

\section{Discussion}

\section{Origins and gene flow across the Andes}

Although we were not able to access populations to the south of the Bloxami range in Chile, it is nevertheless apparent that very limited gene flow across the Andes has rendered the Bloxami populations both genetically and phenotypically distinct from all other burrowing parrots. This further corroborates a previous study using microsatellite loci that showed a clear separation between Chilean and Argentinean populations, but no structure within Argentina [43]. By contrast, cluster analyses of 3 mitochondrial fragments suggest a complex population structure for burrowing parrots in Argentina. Since the Bloxami split is at the root of the species phylogeny, and that this is the only population to not bear any of the signatures of a recent population expansion (Figure 2B/C), we suggest a Chilean origin for this species, with a single migration event across the Andes that gave rise to all extant Argentinean mitochondrial lineages (Figure 3). Although the sampled Chilean lineages coalesce to only 12 - 34 kya, their southern range was not sampled and the Bloxami mismatch distribution (Figure $2 \mathrm{C}$ ) suggests a population with no significant changes in effective population size over time. Furthermore, the network of Bloxami lineages (black circles, Figure 2B) describes a population with several haplotypes in low frequency, none of which are related to each other by fewer than two mutational steps, implying that intermediate and other more distant haplotypes, that could have increased the Bloxami coalescence time, were either lost or not sampled.

In contrast, the histories of all populations in Argentina are characterised by recent (between 9 - 55 kya) expansion (Figure $2 \mathrm{~B} / \mathrm{C}$ ). The migration event across the Andes therefore dates roughly to between $55-126$ kya, to a time when the southern and central reaches of that mountain range were heavily glaciated [e.g. 


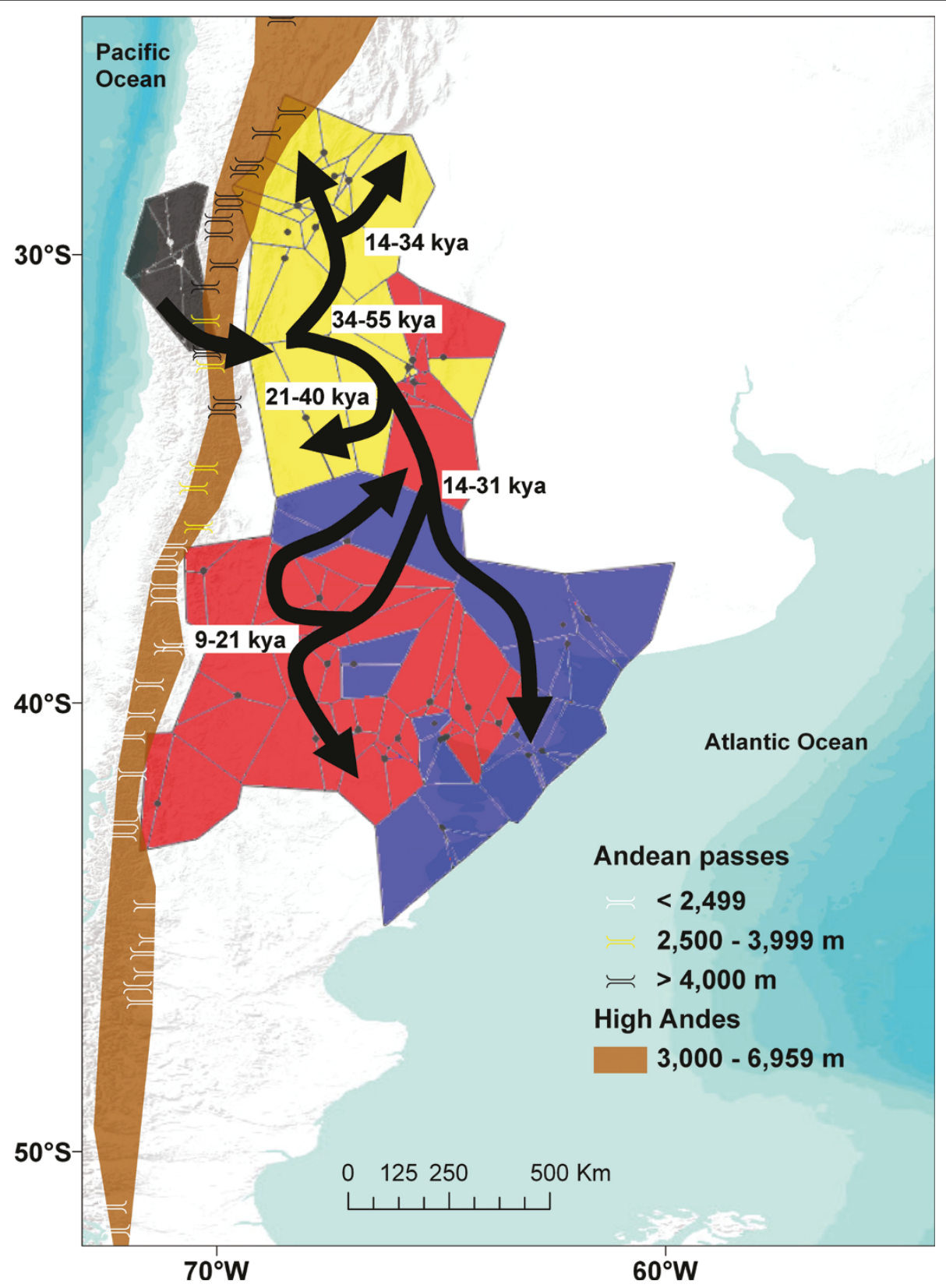

Figure 3 Spatial clustering of multilocus burrowing parrot (Cyanoliseus patagonus) genotypes in landscape space. The most likely hard clustering posterior was superimposed on to a map of the region to convey patterns of spatial clustering of four populations in Chile and Argentina. A model for the colonisation and diversification events that have shaped mitochondrial population structure is also depicted. Each dot represents a sampling location (see also Additional file 1 Table S1). The arrows indicate the migration model proposed for the species. A graphical representation of the high Andes in the region has been added (in light brown) together with the exact location of all known passes in the region.

$[28,31,32,80]]$, making a crossing over the lower $(<2,500$ m) passes in these areas impossible for want of water and shelter until at least 14 kya [80]. Instead, we suggest a crossing over one of the few intermediate $(2,500$ $4,000 \mathrm{~m}$ ) mountain passes to the north of the presentday species distribution (Figure 3). Although rare, recent evidence of exactly such a crossing from Chile into the
Mendoza region of Argentina by a Peruvian pelican (Pelecanus thagus), where all passes are higher than $2,500 \mathrm{~m}$, shows that bird migration across the high Andes is biologically possible [81]. The resulting founder effect of an Andean crossing may also help to explain the contrasting size and plumage differences that exist between bloxami and andinus [34]. 


\section{Gene and phenotype divergence in Argentina}

The initial divergence of Andinus-Patagonus mitochondrial lineages during the late Pleistocene 34 - 55 kya represents a clear asynchrony between genetic and phenotypic divergence times within this species. The two most ancestral haplotypes assigned to the Patagonus1 population (Figure 2A/B) are phenotypically andinus individuals, sampled among andinus locations in the Cuyo region, at least $500 \mathrm{~km}$ from the andinus-patagonus hybrid zone in San Luis. Since older Patagonus haplotypes were not detected, despite a sample of 106 patagonus individuals from across their entire distribution, we propose that phenotypic divergence between Andinus and Patagonus lagged genetic divergence, by 3 - $41 \mathrm{kyr}$, which is the minimum-maximum time difference between the initial Andinus-Patagonus and the Patagonus1-Patagonus2 divergences. Further evidence that phenotypic differences take longer to evolve in this species is the genetic diversification of Patagonus1 from Patagonus2 within Patagonia, which occurred no later than 9 kya, yet the two populations still remain phenotypically indistinguishable from each other. This lag in phenotypic divergence may result from greater lineage sorting among mitochondrial genomes, and whether it holds true for slower evolving unlinked regions such as nuclear introns remains to be investigated.

\section{Colonisation and diversification}

Summarising the results and available information, we propose a model for the colonisation and diversification events to have shaped the distribution of genetic variation in burrowing parrots (Figure 3). The presence of ancestral Patagonus haplotypes within the range of andinus implies that genetic diversification of these two populations occurred in the Cuyo region, with phenotypic diversification occurring later (after 21 kya, see Figure 2A) as Patagonus expanded south-east (see model, Figure 3). Since burrowing parrots are completely dependent on water and suitable strata in which to form nests [e.g. [37]], we predicted the population structure to be a product of isolation and hence local genetic drift. Our results suggest, rather, a low degree of isolation since most sampling localities are similarly diverse, indicating gene flow between them. This is most likely owing to suitable habitats being continuously distributed along river courses and because burrowing parrots are able to make one to four foraging trips to a distance of up to $66 \mathrm{~km}$ from their colonies in a single day [37]. Hence, we conclude that the south-eastern expansion of genetically Patagonus individuals probably followed the courses of the Bermejo-Desaguadero-Atuel, Colorado and Negro river systems, which were already in existence by that time $[28,82]$. By $14-31$ kya, Patagonus was established along river courses, and along the
Atlantic coast of Patagonia (Figure 3). The end of the last glacial maximum (LGM) 14 kya saw the establishment of wetter, more suitable habitats in north-western Patagonia [e.g. [27-30,80]] and possibly promoted further diversification into Patagonus2 between 9 - 21 kya. Spatial clustering shows that the Holocene expansion of Patagonus2 lineages has rendered this population dominant in much of north-western Patagonia, between the Andes and the Atlantic (Figure 3), especially along and to the south of the Río Negro, where only few populations contain Patagonus1 haplotypes in high frequency.

\section{Secondary contact}

Our results convincingly demonstrate the existence of a hybrid zone in the San Luis region, where Patagonus (Patagonus2 in all but one case) haplotypes expanding into the south-eastern range of Andinus resulted in the evolution of an intermediate phenotype: conlara, and this is also the most genetically diverse of the four burrowing parrot taxonomic groupings. The dynamics of hybrid zones are of great interest, especially their potential to give rise to new species or populations [e.g. [11]]. While our results warrant a thorough study of the Andinus-Patagonus hybrid zone using nuclear DNA markers, mitochondrial data reveal several processes of interest. We found no significant difference between the proportion of conlara individuals belonging to Andinus and Patagonus2 $\left(\chi^{2}=0.003, d f=1, P=0.960\right)$ and Andinus and all Patagonus $\left(\chi^{2}=2.7, d f=1, P=0.102\right)$ suggesting, firstly that there is no sex bias in dispersing Patagonus individuals, and secondly that there was no bias by resident Andinus against the choice of invading Patagonus individuals as potential mates. From our phylogeny (Figure 2A), we also conclude that the observed level of introgression resulted from at least four, possibly independent, migration events by Patagonus individuals. Within the Patagonus2 clade, four conlara-undetermined haplotypes comprise an entire sub-clade, suggesting that they resulted from a single successful migration event, and given the depth of this sub-clade, Patagonus2 introgression may date back to at least the latter half of the Holocene (inference, Figure 2A). Similarly, the most ancestral of Andinus haplotypes was carried by a conlara individual and dates back to the coalescence of the Andinus clade (14 - 34 kya). Together with the morphological conformity of the conlara phenotype within its range [83], this result strongly suggests a hybrid zone that has remained stable for several thousand years. The inability of seven polymorphic microsatellite loci to discriminate among Argentinean populations [43] also suggests a hybrid zone that has remained stable long enough for homoplasy to mask phylogeographic signal in hypervariable markers. Since phenotypic variation 
across the andinus-conlara-patagonus continuum, appears to be discretely, rather than continuously partitioned, implying that gene flow out of the hybrid zone is lower that gene flow into it, the possibility of the conlara phenotype being selectively advantageous in the San Luis region cannot be ruled out.

\section{The effect of climate}

Our data show that up to $48 \%$ of the genetic variation can be accounted for by present-day climatic variables, considerably greater than the variation accounted for phenotype and ecoregions. This is even more surprising since ecoregions would normally be expected to co-vary with climate. This lack of variation attributable to ecoregion might be explained by the fact that the two major constraints on burrowing parrots habitat suitability, namely availability of water and cliffs, are not included in ecoregion definitions. Even the significant correlation with present-day climate appears counterintuitive since climatic conditions in the past are more likely to have had an influence over population structure. However, if we consider that the majority of the haplotypes within Patagonus $1 / 2$ and Andinus most likely evolved after the LGM 14 kya or more recently (Figure 2A), and that local climatic conditions have remained relatively similar in the last $8 \mathrm{kyr}$ [e.g. [28-30,80]], this result is less surprising. Conservation implications of this are particularly important in the present-day reality of climate change.

\section{Conservation implications}

The lack of gene flow makes the high Andes an important barrier to migration in burrowing parrots, and possibly in other bird species [e.g. [81]]. This also renders the isolated Bloxami population genetically and phenotypically distinct. This evolutionary significance is important from a conservation and management perspective. Burrowing parrots are listed as "threatened" species in the vertebrate red list of Chile and as such are legally protected [84]. This is because only 5,000 - 6,000 bloxami are distributed in the IV and VII regions of the country $[41,85]$. The size and uniqueness of this population means that further reductions should be avoided.

The situation differs considerably in Argentina, where burrowing parrots are officially considered an abundant agricultural pest (National Law of Defence of Agricultural Production 6704/63), despite agricultural damage occurring only locally $[40,86]$, with very little actual crop damage recorded $[37,44]$. Owing to its persecution as a pest species [[37] and references therein], several colonies have been destroyed or severely reduced in size, including the extirpation of the largest known colony of some 50,000 nests [87]. Collection of burrowing parrots for the pet trade was also encouraged [88] and population reductions continued to reach levels considerable enough for the regional government of the Río Negro province to ban all hunting and trade (resolutions 23-DF-2004, 24-DF-2004, Dirección de Fauna de la Provincia de Río Negro, Argentina), thereby extending legal protection to all but seven Patagonian colonies. This protection effectively includes the bulk of the Patagonus population, approximately 40,000 nests, where genetic diversity is partitioned into two genetically distinct, yet phenotypically indistinguishable populations, which are impossible to manage separately. It should be noted, however, that 37,000 of these nests are located in a single colony - El Cóndor (sampling location 39, Figure 1) [37], which is located in an area undergoing habitat degradation that is estimated to be ten times higher (3.7\% annually) [45] than the world average of $0.4 \%$ [89]. The continued existence of the burrowing parrot in Patagonia is therefore uncertain.

A negative side effect of the recent protection of Patagonian populations is the noticeable increase in commercial value of Andinus populations in the Cuyo region. All available data from this study (Tables 1, 2 $\& 3$ ) and the literature [90], together with unpublished data of 1 colony for which we did not obtain sequences, La Manga stream, La Rioja, 290 nests) show that the total Andinus population numbers no more than 2,000 nests. In contrast to Patagonus, where individuals are genetically but not phenotypically distinguishable, Andinus populations are distinctive both genetically (Figures 2 and 3) and phenotypically [34] from Patagonus, comprising an evolutionary significant unit that appears to be kept isolated by the Andes to the West and a stable hybrid zone to the South-east. We suggest a complete stop of trade in the Cuyo region and the development of conservation measures, particularly of the cliffs with colonies, which are crucial for the survival this population.

Most alterations in the environment, like climate change, are potential sources of new or intensified directional selection on traits important for the fitness of the species living in it [e.g. [91]]. Evolutionary responses take place on a time scale comparable to that of changes in climate, but the degree of adaptation will depend on the interplay of natural selection with processes such as gene flow, genetic drift, mutation and demography [e.g. [92]]. The tight link between genetic variation and climatic variables here reported, in light of the present-day reality of climate change, could lead to important conservation implications in burrowing parrots. Climate change is likely to impose selection pressures on traits important for fitness [e.g. [91]], thus affecting the chances of persistence of this species. Furthermore, climate change could differently affect the four population clusters detected throughout the species range and, in addition, the populations could vary in the rate of 
adaptation. Consequently the outcome of climate change, on top of other environmental constraints (e.g. presence of water and Monte vegetation, occurrence of cliffs), could be particularly important for some of the populations, in particular the currently endangered Bloxami and Andinus populations. Under added selection pressure, such as that imposed by ongoing climate change, populations can respond in roughly three ways: 1) by shifting in abundance and distribution, 2) by going extinct, or 3) by evolving [93]. Even if predicting which one, or even which combinations of them, will occur is difficult [92,93], some likely scenarios can be expected for the burrowing parrot population clusters. Shifts in the distribution could be possible in the case of Bloxami, distributed in Chile. Due to intensive poaching, several cliffs along the historical distribution of the species (Figure 1), which traditional contained colonies, have been found to be empty at present $[41,85]$ (JFM pers. observ.). Provided that water and natural food items are still available in those places, and that the current small size of Bloxami is not further reduced, these colonies could be reoccupied by burrowing parrots. The situation appears to be quite different for the size-reduced Andinus population in the Cuyo region of Argentina (Additional file 4 Figure S1). In this area, only few suitable breeding places (high cliffs close to water and Monte vegetation) are available, leaving this population only two possibilities in case of strong or too sudden climate change: going extinct or evolving. For Patagonus1 and Patagonus2, two genetically distinct, yet phenotypically indistinguishable populations, the situation appears to differ again. In a few occasions, individuals from several colonies of these populations were found to breed in nests dug in human-build structures like shafts of mines, abandoned adobe buildings and wells for collecting water for cattle [94]. Additionally, some suitable breeding places are available in the southernmost as well in the easternmost areas of the historical distribution of the species. Provided the future occurrence of a more benign climate in the South and a release of human-induced pressure in the East, some of those areas could be used by burrowing parrots. However, the currently rapid habitat degradation in the region inhabited by Patagonus1 and Patagonus2 (see above) makes this possibility very uncertain, as in fragmented landscapes, rapid climate change has the potential to overwhelm the capacity for adaptation of the populations and dramatically alter their genetic composition [95]. Altogether, how closely adaptation can be expected to accommodate climate change and the additional pressure of habitat loss and fragmentation, remains a question for further research.

\section{Additional material}

Additional file 1: Table S1. Classification, GenBank accession numbers, and sample locations with detailed climate parameters of 150 burrowing parrots (Cyanoliseus patagonus).

Additional file 2: Table S2. Haplotype distribution of 150 burrowing parrots (Cyanoliseus patagonus).

Additional file 3: Table S3. Divergence estimates using fossil calibration with rate smoothing across three gene partitions in comparison with cytochrome $b$ mutation rates.

Additional file 4: Figure S1. Sample locations (black dots), main places, regions, and ecoregions mentioned in the text, and rivers of Southern South America.

\section{Acknowledgements}

We wish to thank the following persons for helping with sample collection: Orlando Amaya, Brent Barrett, Julio Bufelli, Mirta Carbajal, Gabriel Cortéz, Francesca Cunninghame, Miguel Escobar, Esteban Fernández, Víctor Fratto, Pablo Giovine, Patricia González, Anna Grasse, Guillermo Luna Jorquera, Mariano Linares, Fabián Llanos, Walter Marcial, Gabriela Murga Velasco, Enrique Narvaes, Juanjo Navarro, Sandra Rivera, Oscar Saá, Sergio Sánchez, Lorenzo Sympson, Adalberto Taux, Ricardo Torres, and Luis Valenzuela Riquelme. We also would like to thank the following curators for their help: Friederike Woog and Iris Heynen (Staatliches Museum für Naturkunde Stuttgart), Jean-Louis Martelli (Musée des Confluences, Centre de Conservation et d'Etude des Collections, Lyon), Sylke Frahnert (Museum für Naturkunde Berlin), Marie-Dominique Wandhammer and Dominique Nitka (Musée zoologique de Strasbourg), Alexander Haas and Jakob Hallermann (Zoologisches Museum, Universität Hamburg), Bernd Nicolai (Museum Heineanum, Halberstadt) and Dietrich Heidecke (Zoologisches Sammlungen Halle, Martin-Luther-Universität Halle Wittenberg). This project was partially supported by the World Parrot Trust, the German Ornithologists' Society (Deutsche Ornithologen-Gesellschaft), the Liz Claiborne Art Ortenberg Foundation, the Wildlife Conservation Society, and the Deutsche Forschungsgemeinschaft (QU148-1, Germany). We wish to thank Ann Michels for helping with the application for the necessary permits in Chile. We especially thank Jamie Gilardi, Graham Harris and Bill Conway for crucial support. In Argentina, the present study was carried out under permission of the Dirección de Fauna de la Provincia de Río Negro, Argentina (Exp. no. 143089-DF-98), and the Dirección de Fauna Silvestre, Secretaría de Ambiente de la Nación, Argentina (CITES permits).

\section{Author details}

${ }^{1}$ Max Planck Institute for Ornithology, Vogelwarte Radolfzell, Radolfzell, Germany. ${ }^{2}$ Konrad Lorenz Institute for Ethology, Department of Integrative Biology and Evolution, University of Veterinary Medicine Vienna, Austria. ${ }^{3}$ Department of Evolutionary Biology and Animal Ecology, University of Freiburg, Germany. ${ }^{4}$ Department of Wildlife Ecology and Management, University of Freiburg, Germany. ${ }^{5}$ Proyecto Patagonia Noreste, Río Negro, Argentina. 'aboratorio de Ecología y Diversidad de Aves Marinas, Universidad Católica del Norte, Coquimbo, Chile.

\section{Authors' contributions}

JFM and PQ conceived and designed the study. YM, GS and MS planned the genetic analyses. JFM, PQ, MF and MC carried out the extensive fieldwork. GKM, NK and JFM generated the molecular data. JFM, NK and YM participated in bioinformatic analyses. YM, JFM and PQ were responsible for data analysis and drafted the manuscript. GS and MS reviewed the final draft of the manuscript. All authors read and approved the final manuscript.

\section{Competing interests}

The authors declare that they have no competing interests.

Received: 2 February 2011 Accepted: 15 June 2011

Published: 15 June 2011 


\section{References}

1. Faria PJ, Guedes NMR, Yamashita C, Martuscelli P, Miyaki CY: Genetic variation and population structure of the endangered Hyacinth Macaw (Anodorhynchus hyacinthinus): implications for conservation. Biodiversity and Conservation 2008, 17:765-779.

2. Joseph L, Dolman G, Donnellan S, Saint KM, Berg ML, Bennett ATD: Where and when does a ring start and end? Testing the ring-species hypothesis in a species complex of Australian parrots. Proc $R$ Soc Lond $B$ 2008, 275:2431-2440

3. Ribas CC, Miyaki CY, Cracraft J: Phylogenetic relationships, diversification and biogeography in Neotropical Brotogeris parakeets. J Biogeogr 2009, 36:1712-1729.

4. Holderegger R, Wagner HH: Landscape genetics. BioScience 2008, 58:199-207.

5. Hanski I: Metapopulation dynamics. Nature 1998, 396:41-49.

6. Gibbs JP: Demography versus habitat fragmentation as determinants of genetic variation in wild populations. Biol Conserv 2001, 100:15-20.

7. Holzhauer SIJ, Ekschmitt K, Sander A-C, Dauber J, Wolters V: Effect of historic landscape change on the genetic structure of the bush-cricket Metrioptera roeseli. Landsc Ecol 2006, 21:891-899.

8. Keyghobadi N: The genetic implications of habitat fragmentation for animals. Can J Zool 2007, 85:1049-1064.

9. Koscinski D, Yates AG, Handford P, Lougheed SC: Effects of landscape and history on diversification of a montane, stream-breeding amphibian. $J$ Biogeogr 2009, 36:255-265.

10. Frankham R: Do island populations have less genetic variation than mainland populations? Heredity 1997, 78:311-327.

11. Grant PR, Grant BR: Hybridization and bird species. Science 1992 256:193-197.

12. Bell DA: Genetic differentiation, geographic variation and hybridization in gulls of the Larus glaucescens-occidentalis complex. Condor 1996, 98:527-546.

13. Parsons J, Olson SL, Braun MJ: Unidirectional spread of secondary sexual plumage traits across an avian hybrid zone. Science 1993, 260:1643-1646.

14. Grant PR, Grant BR: Phenotypic and genetic effects of hybridization in Darwin's Finches. Evolution 1994, 48:297-316.

15. Rhymer JM, Williams MJ, Braun MJ: Mitochondrial analysis of gene flow between New Zealand mallards (Anas platyrhynchos) and grey ducks ( $A$. superciliosa). Auk 1994, 111:970-978.

16. Pierotti $R$, Annett CA: Hybridization and male parental investment in birds. Condor 1993, 95:670-679.

17. Dowling TE, Secor CL: The role of hybridization and introgression in the diversification of animals. Annu Rev Ecol Syst 1997, 28:593-619.

18. Avise JC, Walker D: Pleistocene phylogeographic effects on avian populations and the speciation process. Proc R Soc Lond B 1998, 265:457-463.

19. Kim I, Phillips CJ, Monjeau JA, Birney EC, Noack K, Pumo DE, Sikes RS, Dole JA: Habitat islands, genetic diversity, and gene flow in a Patagonian rodent. Molecular Ecology 1998, 7:667-678.

20. Martinez JJ, Gonzalez-Ittig RE, Theiler GR, Ojeda R, Lanzone C, Ojeda A, Gardenal CN: Patterns of speciation in two sibling species of Graomys (Rodentia, Cricetidae) based on mtDNA sequences. J Zool Syst Evol Res 2010, 48:159-166.

21. Ojeda AA: Phylogeography and genetic variation in the South American rodent Tympanoctomys barrerae (Rodentia: Octodontidae). J Mammalogy 2010, 91:302-313.

22. Morando M, Avila LJ, Baker J, Sites JW: Phylogeny and phylogeography of the Liolaemus darwinii complex (Squamata: Liolaemidae): Evidence for introgression and incomplete lineage sorting. Evolution 2004, 58:842-861

23. Avila LJ, Morando M, Sites JW: Congeneric phylogeography: hypothesizing species limits and evolutionary processes in Patagonian lizards of the Liolaemus boulengeri group (Squamata: Liolaemini). Biol J Linn Soc 2006, 89:241-275.

24. Yoke MM, Morando M, Avila LJ, Sites JW: Phylogeography and genetic structure in the Cnemidophorus longicauda complex (Squamata, Teiidae). Herpetologica 2006, 62:420-434.

25. Koscinski D, Handford P, Tubaro PL, Sharp S, Lougheed SC: Pleistocene climatic cycling and diversification of the Andean treefrog, Hypsiboas andinus. Mol Ecol 2008, 17:2012-2025.

26. Alonso Roldan V, Rossi Fraire H, Navarro JL, Gardenal CM, Martella MB: Genetic structure of Greater Rhea (Rhea americana) populations in two regions with different land-uses in central Argentina. Emu 2009, 109:214-221.

27. Iriondo $\mathrm{MH}$, Garcia NO: Climatic variations in the Argentine Plains during last 18.000 years. Palaeogeo, Palaeoclim, Palaeoecol 1993, 101:209-220.

28. Iriondo M: La Pampa. In Climas cuaternarios en America del Sur. Edited by: Argollo J, Mourguiart P. La Paz, Bolivia: Institut Français de Recherche Scientifique pour le Développement en Coopération; 1995:283-306.

29. Tonni EP, Cione AL: Los mamíferos como indicadores de cambios climáticos en el Cuatemario de la región pampeana de la Argentina. In Climas cuaternarios en America del Sur. Edited by: Argollo J, Mourguiart P. La Paz, Bolivia: Institut Français de Recherche Scientifique pour le Développement en Coopération; 1995:319-326.

30. Cione AL, Tonni EP, Soibelzon L: The broken zig-zag: Late Cenozoic large mammal and tortoise extinction in South America. Rev Mus Argentino Cienc Nat, n s 2003, 5:1-19.

31. Clapperton CM: The glaciation of the Andes. Quat Scie Rev 1983, 2:83-155.

32. Vuilleumier BS: Pleistocene changes in the flora and fauna of South America. Science 1971, 173:771-780.

33. Tambussi C, Acosta Hospitaleche C, Horlent N: La avifauna del Cuaternario de Argentina: inferencias paleoambientales a partir del registro de los Psittacidae. Mon Soc Hist Nat Balears 2007, 14:69-80.

34. Darrieu CA: Las razas geográficas de Cyanoliseus patagonus (Aves: Psittacidae). Neotropica 1980, 26:207-216.

35. Badano El, Cavieres LA, Molina-Montenegro MA, Quiroz CL: Slope aspect influences plant association patterns in the Mediterranean matorral of central Chile. J Arid Environm 2005, 62:93-108.

36. López RP, Larrea Alcázar D, Macía MJ: The arid and dry plant formations of South America and their floristic connections: new data, new interpretation? Darwiniana 2006, 44:18-31.

37. Masello JF, Pagnossin ML, Sommer C, Quillfeldt P: Population size, provisioning frequency, flock size and foraging range at the largest known colony of Psittaciformes: the Burrowing Parrots of the northeastern Patagonian coastal cliffs. Emu 2006, 106:69-79.

38. Masello JF, Lubjuhn T, Quillfeldt P: Is the structural and psittacofulvinbased colouration of wild Burrowing Parrots Cyanoliseus patagonus condition dependent? J Avian Biol 2008, 39:653-662

39. Nores M, Yzurieta D: Especiación en las Sierras Pampeanas de Córdoba y San Luis (Argentina), con descripción de siete nuevas subespecies de aves. Hornero 1983, 88-102, № Extraordinario.

40. Bucher EH, Rinaldi S: Distribución y situación actual del loro barranquero (Cyanoliseus patagonus) en la Argentina. Vida Silv Neotrop 1986, 1:55-61.

41. Rojas Martínez ME: Estudio de la interacción entre las poblaciones de loro tricahue Cyanoliseus patagonus bloxami, y la actividad agrícola en las comunas de Vicuña y Monte Patria, Región de Coquimbo, Chile Santiago de Chile: Servicio Agrícola y Ganadero, Ministerio de Agricultura, Gobierno de Chile; 2008.

42. Bó NA: Notas preliminares sobre la avifauna del nordeste de San Luis. Hornero 1965, 10:251-268.

43. Klauke N, Masello JF, Quillfeldt P, Segelbacher G: Isolation of tetranucleotide microsatellite loci in the burrowing parrot (Cyanoliseus patagonus). Journal of Ornithology 2009, 150:921-924.

44. Failla M, Seijas VA, Quillfeldt P, Masello JF: Potencial impacto del loro barranquero (Cyanoliseus patagonus): evaluación de percepción de daño en Patagonia Nordeste, Argentina. Gestión Ambiental 2008, 16:27-40.

45. Pezzola A, Winschel C, Sánchez R: Estudio multitemporal de la degradación del monte nativo en el partido de Patagones - Buenos Aires INTA-Ascasubi, Ascasubi, Buenos Aires, Argentina; 2004.

46. Masello JF, Marchesan M, Quillfeldt P: Zehn Jahre Forschung in der größten Papageienkolonie der Welt - Teil 1. Die Felsensittiche im Nordosten Patagoniens. Papageien 2008, H.12/2008:426-429.

47. Masello JF, Pagnossin GA, Palleiro GE, Quillfeldt P: Use of miniature security cameras to record behaviour of burrow-nesting birds. Vogelwarte 2001, 41:150-154.

48. Masello JF, Sramkova A, Quillfeldt P, Epplen JT, Lubjuhn T: Genetic monogamy in burrowing parrots Cyanoliseus patagonus? J Avian Biol 2002, 33:99-103.

49. Masello JF, Pagnossin ML, Lubjuhn T, Quillfeldt P: Ornamental noncarotenoid red feathers of wild Burrowing Parrots. Ecol Res 2004, 19:421-432.

50. Masello JF, Choconi RG, Sehgal RMN, Tell LA, Quillfeldt P: Blood and intestinal parasites in wild Psittaciformes: a case study of Burrowing Parrots (Cyanoliseus patagonus). Orn Neotropical 2006, 17:515-529. 
51. Masello JF, Choconi RG, Helmer M, Kremberg T, Lubjuhn T, Quillfeldt P: Do leucocytes reflect condition in nestling burrowing parrots (Cyanoliseus patagonus) in the wild? Comp Biochem Physiol A 2009, 152:176-181.

52. Masello JF, Lubjuhn T, Quillfeldt P: Hidden dichromatism in Burrowing Parrots Cyanoliseus patagonus as revealed by spectrometric colour analysis. Hornero 2009, 24:47-55.

53. Masello JF, Quillfeldt P: Chick growth and breeding success of the Burrowing Parrot. Condor 2002, 104:574-586.

54. Masello JF, Quillfeldt P: Body size, body condition and ornamental feathers of Burrowing Parrots: Variation between years and sexes, assortative mating and influences on breeding success. Emu 2003, 103:149-161.

55. Masello JF, Quillfeldt P: Are haematological parameters related to body condition, ornamentation and breeding success in wild burrowing parrots Cyanoliseus patagonus? J Avian Biol 2004, 35:445-454

56. Masello JF, Quillfeldt P: Consequences of La Niña phase of ENSO for the survival and growth of nestling Burrowing Parrots on the Atlantic coast of South America. Emu 2004, 104:337-346.

57. Masello JF, Quillfeldt P: Klimawandel und Brutverhalten: erfolgreich brüten in wechselhafter Umwelt? Eine Fallstudie am Felsensittich. Vogelwarte 2008, 46:302-303.

58. Bucher EH, Bertin MA, Santamaria AB: Reproduction and molt in the burrowing parrot. Wilson Bull 1987, 99:107-109.

59. Astuti D, Azuma N, Suzuki H, Higashi S: Phylogenetic relationships within parrots (Psittacidae) inferred from mitochondrial cytochrome-b gene sequences. Zool Sci 2006, 23:191-198.

60. Palumbi SR: Nucleic acids II: The polymerase chain reaction. Molecular Systematics. 2 edition. Sunderland, Massachusetts: Sinauer Associates, Inc; 1996.

61. Eberhard JR, Bermingham E: Phylogeny and biogeography of the Amazona ochrocephala (Aves: Psittacidae) complex. Auk 2004, 121:318-332.

62. Librado P, Rozas J: DnaSP v5: A software for comprehensive analysis of DNA polymorphism data. Bioinformatics 2009, 25:1451-1452.

63. Corander J, Tang J: Bayesian analysis of population structure based on linked molecular information. Mathematical Biosciences 2007, 205:19-31

64. Jobb G, von Haeseler A, Strimmer K: TREEFINDER: a powerful graphical analysis environment for molecular phylogenetics. BMC Evolutionary Biology 2004, 4:e18.

65. Jobb G: TREEFINDER.[http://www.treefinder.de], (Version of October 2008). 2008. Munich. Distributed by the author.

66. Bandelt HJ, Forster P, Röhl A: Median-joining networks for inferring intraspecific phylogenies. Mol Biol Evol 1999, 16:37-48.

67. Rogers $A R$, Harpending $H$ : Population growth makes waves in the distribution of pairwise genetic differences. Mol Biol Evol 1992, 9:552-569.

68. Excoffier L, Lischer HEL: Arlequin suite ver 3.5: A new series of programs to perform population genetics analyses under Linux and Windows. Mol Ecol Res 2010, 10:564-567.

69. Tonni EP, Laza JH: Las aves de la Fauna Local Paso de Otero (Pleistoceno Tardio) en la Provincia de Buenos Aires. Su significación ecológica, climática y zoogeográfica. Ameghiniana 1980, 17:313-322.

70. Tambussi CP, Noriega J, Tonni EP: Late Cenozoic birds of Buenos Aires Province (Argentina): an attempt to document quantitative faunal changes. Palaeogeo, Palaeodim, Palaeoecol 1993, 101:117-129.

71. Tambussi C, Acosta Hospitaleche C, Rinderknecht A, Ubilla M: Parrots (Aves, Psittaciformes) in the Pleistocene of Uruguay. Ameghiniana 2009, 46:431-435.

72. Acosta Hospitaleche Cl, Tambussi CP: Cyanoliseus patagonopsis nov. sp. (Aves, Psittaciformes) del Pleistoceno de Punta Hermengo, provincia de Buenos Aires. Cyanoliseus patagonopsis nov. sp. (Aves, Psittaciformes) of the Pleistocene of Punta Hermengo, Buenos Aires Province. Ameghiniana 2006, 43:249-253.

73. Tonni EP: Cyanoliseus ensenadensis (Cattoi) nov. comb. (Aves, Psittaciformes) del Pleistoceno Medio de la provincia de Buenos Aires. Ameghiniana 1972, 2:145-148.

74. Weir JT, Schluter D: Calibrating the avian molecular clock. Molecular Ecology 2008, 17:2321-2328

75. Drummond AJ, Rambaut A: BEAST: Bayesian evolutionary analysis by sampling trees. Bmc Evolutionary Biology 2007, 7:214.

76. Anderson MJ: DISTLM v.5: a FORTRAN computer program to calculate a distance-based multivariate analysis for a linear model. (v.5). Auckland,
New Zealand, Department of Statistics, University of Auckland; 2004 [http:// www.stat.auckland.ac.nz/ mja/Programs.htm\#Mine].

77. Hijmans RJ, Cameron SE, Parra JL, Jones PG, Jarvis A: Very high resolution interpolated climate surfaces for global land areas. Int J Climatol 2005, 25:1965-1978.

78. Anderson MJ: DISTLM forward: a FORTRAN computer program to calculate a distance-based multivariate analysis for a linear model using forward selection. Auckland, New Zealand, Department of Statistics, University of Auckland; 2003 [http://www.stat.auckland.ac.nz/ mja/Programs. htm\#Mine].

79. François $\mathrm{O}$, Ancelet $\mathrm{S}$, Guillot $\mathrm{G}$ : Bayesian clustering using hidden Markov random fields in spatial population genetics. Genetics 2006, 174:805-816.

80. McCulloch RD, Bentley MJ, Purves RS, Hulton NRJ, Sugden DE, Clapperton CM: Climatic inferences from glacial and palaeoecological evidence at the last glacial termination, southern South America. J Quat Scie 2000, 15:409-417.

81. Elías A: Nuevo registro del pelícano pardo (Pelecanus thagus) en la Argentina. Nuestras Aves 2008, 53:48.

82. Suriano JM, Ferro G, Dalponte M: Convenio Dirección de Minería de Río Negro-Segemar: Geología y Recursos Minerales de la Hoja 3966-IV, Choele Choel y del Sector Rionegrino de las Hojas 3963-III, Colonia Juliá; 4163-IIII, General Conesa y 4163-II-IV, Viedma Viedma; 1999.

83. Bruno G, Torres R: Distribución, status, caracterización del hábitat, y diagnóstico de uso, del loro barranquero (Cyanoliseus patagonus) en el centro de Argentina Córdoba, Proyecto Elé; 2006.

84. Glade A, (ed): Libro rojo de los vertebrados terrestres de Chile. 2 edition. Santiago de Chile: CONAF; 1993.

85. Naranjo Navia J: Análisis de las variaciones poblacionales en la especie Cyanoliseus patagonus bloxami, (loro tricahue) en la VII Región de Chile. Dinámica de Poblaciones, Universidad de Chile, Santiago de Chile; 2005, Report, $20 \mathrm{pp}$.

86. Bucher EH: Neotropical parrots as agricultural pests. In New world parrots in crisis: solutions from conservation biology. Edited by: Beissinger SR, Snyder NFR. New York and London: Smithsonian Institution Press; 1992:201-219.

87. Voitzuk L: El loro barranquero, plaga agrícola del sud de la provincia de Buenos Aires. Bol Fitosanitario 1975, 48:31-34

88. Moschione FN, Banchs RA: Proyecto Calas. Una experiencia de manejo adaptativo para el aprovechamiento sustentable de psitácidos y como estrategia de conservación de sus habitats en la Argentina. In Manejo de Fauna Silvestre en la Argentina. Programas de uso sustentable. Edited by: Bolkovic ML, Ramadori D. Buenos Aires: Dirección de Fauna Silvestre; 2006:27-37.

89. Balmford A, Green RE, Jenkins M: Measuring the changing state of nature. Trends Ecol Evol 2003, 18:326-330.

90. Moschione F, González MA: Distribución del Loro Barranquero Cyanoliseus patagonus andinus en la Provincia de Salta. Libro de resúmenes. XI Reunión Argentina de Ornitología Aves Argentinas, Buenos Aires; 2005, 10.

91. Gienapp P, Teplitsky C, Alho JS, Mills JA, Merilä J: Climate change and evolution: disentangling environmental and genetic responses. Molecular Ecology 2008, 17:167-178.

92. Davis MB, Shaw RG, Etterson JR: Evolutionary responses to changing climate. Ecology 2005, 86:1704-1714.

93. Holt RD: The Microevolutionary Consequences of Climate Change. Trends in Ecology \& Evolution 1990, 5:311-315.

94. Masello JF, Quillfeldt P: La colonia de loros barranqueros en la costa rionegrina de El Cóndor. Un patrimonio mundial. In Las mesetas patagónicas que caen al mar: la costa rionegrina. Edited by: Masera RF, Lew J, Serra Peirano G. Viedma: Ministerio de Familia, Gobierno de Río Negro, Argentina; 2005:349-371.

95. Jump AS, Peñuelas J: Running to stand still: adaptation and the response of plants to rapid climate change. Ecology Letters 2005, 8:1010-1020.

doi:10.1186/1742-9994-8-16

Cite this article as: Masello et al:: The high Andes, gene flow and a

stable hybrid zone shape the genetic structure of a wide-ranging South American parrot. Frontiers in Zoology 2011 8:16. 